4. Сергієнко Л.В., Дзюбенко О.М., Ожго С.В. Державна екологічна політика України та правовий механізм їі формування і реалізації. Економіка, управління та адміністрування. 2019. № 3(89). C. 191-200.

DOI https://doi.org/10.30525/978-9934-26-005-6-5

\title{
ПСИХОЛОГІЧНІ АСПЕКТИ ЯВИЩА КОРУПЦЇ̈ В СИСТЕМІ ДЕРЖАВНОГО УПРАВЛІННЯ УКРАЇНИ
}

\author{
Гурісвська В. М. \\ кандидат наук з державного управління, \\ доцент кафедри парламентаризму \\ та політичного менеджменту \\ Національної академії державного управління \\ при Президентові України \\ м. Київ, Украӥна
}

Корупція як негативне соціальне явище $є$ джерелом економічних, політичних і соціальних ризиків для українського соціуму. В публічному управлінні України, незважаючи на значну популярність у вживаності, продовжує демонструвати свою стійкість, що дозволяє припустити існування факторів, які не враховуються в державних стратегіях боротьби з корупцією.

Таким фактором, перш за все, $є$ психогенна природа явища корупції, що означає звертання до глибинної сутності існуючої проблеми і усвідомлення її системо-твірного характеру.

Більшість наукових досліджень визначають корупцію як конфлікт між діями посадової особи та інтересами його працедавця, або як конфлікт між діями виборної особи i інтересами суспільства (М. Вебер, Р. Мертон, М. Джонстон, Я. Кузьмінов і ін.). 
На глибші витоки даної проблеми вказував Т. Гоббс, який зазначив, що корупція $\epsilon$ корінь, з якого випливає за всіх часів $\mathrm{i}$ при будь-яких спокусах презирство до всіх законів.

Дане твердження звертає нашу увагу на роль суб'єктивних факторів у аналізі даної проблеми, та роль системних динамік та системної взаємозумовленості в публічному управлінні.

Спираючись на системних принципах аналізу даного явища, для iii вирішення важливим, на наш погляд є наступні складові:

1. проблема може бути вирішена лише тоді, коли дозріла готовність іiі вирішувати і існує високий рівень мотивації усіх іiі членів;

2. якщо зміни відбуваються на найвищих рівнях, то інші рівні швидко інтегрують і адаптуються до змін;

3. проблема не може бути вирішена, поки не усвідомлена їі вигода, потреба і те, яким чином її можна задовольнити у інший спосіб;

4. проблема може маскувати собою іншу, більш серйозну проблему, про яку не говорять, проте вона є більш складнішою для розв'язання;

5. змінивши хоча б один елемент системного алгоритму, ми змінюємо всю систему;

Розглянемо більш детальніше кожен 3 принципів. Щодо першого його значення: навіть багато зусиль не завжди приводить до результату. Іноді більш успішно працює «менше» та «краще». «Кращим» у цьому сенсі виступає не просто більше діяльності, а розуміння глибинних потреб та мотивів до цієї діяльності. Як говорив великий український філософ Г. Сковорода: Можна привести коней до водопою, але не можна змусити їх пити воду. На рівні суспільства, поки не задоволені найнижчі потреби, вищі не будуть формуватися. Тож чи може собі українське суспільство вже зараз дозволити боротьбу з цим явищем, враховуючи збіднілу, виснажену військовим конфліктом країну?

Друге положення. Як зазначав Махатма Ганді: - Ми самі маємо стати тими змінами, що хочемо помічати у світі». Бути прикладом для інших та власною поведінкою демонструвати чесноти, саме це так необхідно сьогодні в українському соціумі. 
На противагу цьому, спостерігаємо явища, коли закони i справедливість носять вибірковий характер, можливість бути почутим ще не стала нормою, а кругообіг паперів, набув більшої цінності, аніж державні службовці, які працюють в системі.

Третє положення пов' язане з «вигодами» від цього явища. В цьому аспекті, «явище корупції має не тільки деструктивне але i функціональне значення, оскільки виступає компенсаторним механізмом, який регулює недостатність системної взаємодії. А саме: невідповідність професійних навантажень 3 оплатою праці; непрозорість системи службових заохочень; відсутність легальності відбору та кваліфікації персоналу; не гнучкість у наданні державних послуг; надмірна бюрократизація при прийнятті управлінських рішень; відсутність мобільності і простоти на противагу зайвої бюрократизації; складність у прийнятті індивідуального рішення окремих запитів; залежність працівників від адміністрації; монопольна влада чиновників; жорсткі правила; відсутність механізмів за яких є можливість кожного бути почутим.

Щоб зрозуміти всю складність явища, необхідно усвідомлювати, яка потреба стоїть за схемою протиправної взаємодії. 3 цієї точки зору, явище корупції $\epsilon$ системостабілізуючим фактором в державному управлінні, оскільки дає визнання людині, адже звернення до конкретної особи дає можливість визнати індивідуальні здібності, проявити владу вирішувати питання, підтримувати компетенцію, професіоналізм i посаду. Тобто, компенсується потреба у визнанні і фігура службовця виходить з бюрократичного паперового потоку на перший план. Одночасно, чиновник бере на себе відповідальність за власний вплив і за те, щоб бажані або певні зміни відбулися. Він, в свою чергу, дає визнання важливості конкретної людини, увагу до приватного запиту, гарантує рішення. Так система забезпечила реалізацію потреби деструктивно, a також знайшла i створила спосіб самозбереження. Таким чином, негативне явище корупції, в якійсь мірі, відіграє позитивну роль для учасників системи державного управління. Корупція, як дзеркало відображас глибинну потребу, яка не задовольнясться і знаходить 28 
заміщення через прояв деструктивного сценарію. Ця проблема, розкриває дозрілу потребу в побудові якісно нових відносин між державною владою і суспільством, на основі визнання, взаєморозуміння i поваги до кожної окремої особистості» [2, с. 135].

Четверте і п'яте положення цієї проблеми пов'язане 3 припущенням, чи не маскує дана проблема ще більшу проблему, яка до того ж, ще не усвідомлена і не визнана.

Зокрема, подальшого дослідження вимагає гіпотеза, за якою явище корупції розглядається як внутрішній конфлікт в суспільстві, організації, системі державної влади, що відображає невідповідність між принципами, законами та соціальними явищами; неузгодженість між індивідуальним і соціальним, державним. Цей конфлікт проявляється далі в системі державного управління як неузгодженість між внутрішнім i зовнішнім, між індивідуальним і колективним.

Е. Дюрекгейм, описував даний конфлікт як явище ціннісної аномії - стан суспільства, за якого помітна частина його членів, знаючи про існування зобов'язуючих їх норм, ставиться до них негативно або байдуже. Це призводить до девальвації i руйнування цивілізованих соціальних регуляторів поведінки людей, таких як: культура, традиції, норми моралі, права, релігія, суспільна думка.

Такі суспільні стани спричинені травматичним минулим досвідом підміни цінностей, за яких цінність особистості, іiі життя і свобода була принесена в жертву заради майбутнього, яке не здійснилося.

В цілому, можна дійти висновку про необхідність фокусування уваги на формуванні культури та введення постійних практик надання зворотного зв’язку як механізму взаємодії, що підвищить значимість окремої індивідуальної думки, ролі особистості у прийнятті державно-управлінських рішень, сприятиме більшій «включеності» та пов'язаності 3 системою державного управління.

Саме психологічні фактори цього питання, що включають: важливість формування мотивації діяльності, узгодження та прояснення рішень, мають стати необхідною складовою 
взаємодії як в державному управлінні так і між державою i суспільством. Така робота потребує психологічного осмислення даної проблеми, визнання важливості психологічного фактора явища корупції та залучення соціально-психологічних технологій до побудови комплексного підходу у боротьбі 3 даною проблемою.

3 психологічної точки зору, Україна за допомогою цього негативного явища доходить до «усвідомлення своєї ролі та власної ідентичності. Таким чином, явище корупції є болючим але закономірним процесом, «печаткою цивілізаційної людини», оскільки він покликаний привести до згоди природу і культуру всередині самого себе». Отже, необхідно більше усвідомлювати застарілі ідеології, що сприяють формуванню залежного суспільства і спрямовувати громадську думку на подолання самознищувальних впливів [2, с. 135].

В зв'язку з цим, враховуючи системні фактори розвитку, за яких рівень впливу в кризових станах може відбуватися під впливом навіть малих змін, проте суттєво залежить від якості такого впливу. Рівень впливовості визначається наступними чинниками, а саме: мотивація, наміри, усвідомленість, узгодженість, проясненість між всіма членами системної взаємодії, особистісною включеністю у діяльність, що i зумовлює стійкість і адаптивність до змін.

Системний погляд на вирішення даної проблеми розширяє поле для побудови дієвої стратегії, яка спирається на те, що проблема - $є$ лише «певною полярністю», що прагне свого розширення через побудову «нового порядку» на відміну від боротьби 3 явищем. Тобто, ключ вирішення даної проблеми знаходиться в самій проблемі, тож замість стратегії «подолання», можливо більш дієвим буде стратегія нової культури «українського успіху» на засадах поваги, визнання і прийняття українських реалій.

\section{Література:}

1. Гурієвська В.M. Психологічні аспекти корупції: навчально-метод. рек. Навчально-метод. рек. / Уклад.: В.М. Гурієвська - К. : НАДУ, 2011. - 53 с. 
2. Гурієвська В.М. Явище корупції як психологічний феномен у системі державного управління в Україні. С.135. // Публічне врядування в Україні: стан, виклики та перспективи розвитку: матеріали щоріч. Всеукр. наук.-практ. конф. за міжнар. участю, (Київ, 25 трав. 2018 р.) : у 5 т. / за заг. ред. В. С. Куйбіди, та ін. - Київ : НАДУ, 2018. - Т. 5. - 176 с. - Режим доступу: http://academy.gov.ua/pages/dop/150/files/2ed7ac0c-5432-4765-bf95 976434aef39e.pdf

3. Дюркгейм Э. О разделении общественного труда. / Э. Дюркгейм - М. : Наука, 1996. С. 370.

4. Порта Д. Брудні оборудки: учасники, ресурси та механізми політичної корупції / Порта Донатела дела, А. Ванучі. - К. : K.I.C., 2006. - 302 с.

DOI https://doi.org/10.30525/978-9934-26-005-6-6

\title{
МЕХАНІЗМИ ЗАПРОВАДЖЕННЯ ІННОВАЦІЙНИХ ІНСТРУМЕНТІВ ОРГАНІВ ВЛАДИ 3 ГРОМАДСЬКІСТЮ В УМОВАХ ДЕЦЕНТРАЛІЗАЦЇ̈
}

\author{
Динник І. П. \\ кандидат наук з державного управління, \\ провідний фахівець сектору контролю за виконанням рішень \\ відділу управління та адміністрування \\ Національного авіаційного університету \\ м. Київ, Україна
}

Здійснення реформи децентралізації сприяло зростанню ініціатив із стимулювання громадської участі у місцевому самоврядуванні. Організації місцевого самоврядування (ОМС) намагаються підвищити інтерес мешканців до участі в розвитку своєї громади через різні демократичні інструменти. Значну роль у поширенні практик прямого ухвалення рішень відіграють 